\title{
Csinta
}

\section{Implementation of Geolocation and Jquery Latest Eor Salesman Monitoring in Android Based Applications}

\author{
Ganda Yoga Swara ${ }^{1}$, Putri Mandarani ${ }^{2}$, Giatman ${ }^{3}$, Syahril $^{4}$ \\ ${ }^{1,2}$ Fakultas Teknik, Institut Teknologi Padang \\ ${ }^{3,4}$ Fakultas Teknik, Universitas Negeri Padang \\ Igandayogaswara@itp.ac.id, ${ }^{2}$ pmandarani@itp.ac.id, ${ }^{3}$ giatman@ft.unp.ac.id, \\ syahril@ft.unp.ac.id
}

\begin{abstract}
The purpose of this study is to design a sales activity monitoring application by utilizing the existing GPS on a smartphone. This research is an experimental research with the waterfall method. There are 5 stages in the waterfall method, namely requirements analysis, system design, implementation, integration \& testing, operation \& maintenance. Testing is done by testing the latest geolocation and jquery to see the success, failure or delay in the three test locations. The result of this research is that under the tree the highest success rate is 0.875, the lowest failure rate is 0.125 and the smallest delay (distance between data entry) is 0.45. The conclusion of this study is that the tracking system using Geolocation and the Latest jQuery if implemented in an open space with conditions under trees gets the highest rating compared to other test locations.
\end{abstract}

Keywords: Sales monitoring, GPS, Geolocation and jQuery Latest

\section{Introduction}

Technology is developing in the current era of globalization increasingly rapidly, so inevitably it requires users and technology connoisseurs to adapt to follow these developments. One technology that is developing very rapidly is a mobile phone or what is commonly called a mobile phone. Currently, mobile phones generally have functions such as calls, video calls, sending messages in the form of text and multimedia elements (sound, images and video), internet access, audio and video file players, photo and video image capture cameras, multimedia file editors. text and images), as well as GIS (Geographic Information System) and GPS (Global Positioning System) functions. Mobile phones with complete functions are also called smart phones or smartphones. [5]

$\mathrm{CV}$. Dygal Bersaudara is a private company that has not used information systems in carrying out salesman performance monitoring activities. Data about the process of selling goods and the expected targets for salesmen are still in the form of documents and archives. So that data processing becomes inefficient and effective. By utilizing technology from GPS that has been integrated with smartphones, this research aims to build and implement an application to monitor the position of salesmen while working. By knowing the position of the salesman, the company monitors the salesman's performance. [1]

GPS is a location notification technology that is widely used today. GPS is a radio navigation system for determining location using satellites [8]. Currently GPS can be used for both military and civilian users [2]. This GPS system can monitor and find out the location of an object you want to know anywhere on the earth's surface. The GPS system can be used by anyone free of charge, as long as you have the necessary equipment and software. Many applications can be developed with this GPS system, including applications that can help to monitor motorized vehicles. By using GPS technology it is possible to be able to follow vehicle tracks and support notifications to be able to follow vehicle tracks and support notifications of the latest travel information [4]. 


\section{Cisinta}

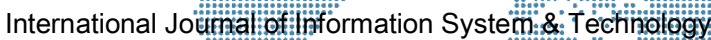

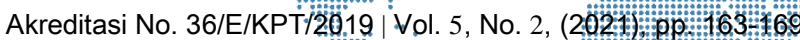

Research with the topic of monitoring sales activities has been carried outubuit [2] in his research explaining the monitoring application to determine salesman Furthermore, in research [7] explained in his research about the applicâtion to determine the list of salesmen visits. In this study, a salesman activity monitoring system was designed. In its design, this application will be equipped with excellent features, namely the tracking system. With this feature, users can track where each other is. The tracking feature is built by using geolocation to retrieve coordinates and jQuery Latest to refresh coordinates. Geolocation is a feature of the GoogleMap API that is used to get coordinates from the user and jQuery Latest is a JavaScript library that contains a function to refresh the page without having to reload an HTML page, in this study jQuery Latest is used to refresh the input coordinates generated. by geolocation.

\section{Research Metodology}

This research is an experimental research, with the waterfall method. There are several data collection techniques used to obtain precise and accurate data and information, including:

a) Literature Study: Conducted by studying several literature books related to this research.

b) Interview: Collecting data by holding a question and answer session with related parties.

c) Observation: Through the Internet to get an overview of applications and other information that supports research.

Waterfall Model is a type of research that emphasizes the process to produce or develop and validate a product [6]. The process is like:

1) Requirements Analysis

At this stage the system developer needs a communication that aims to understand the software required by the user and the limitations of the software. This information can usually be obtained through interviews, surveys or discussions.

2) System Design

In the design process, the requirements are translated into a software design that can be estimated before the coding process is made. This process focuses on data structure, software architecture, interface representation, and procedural algorithm details.

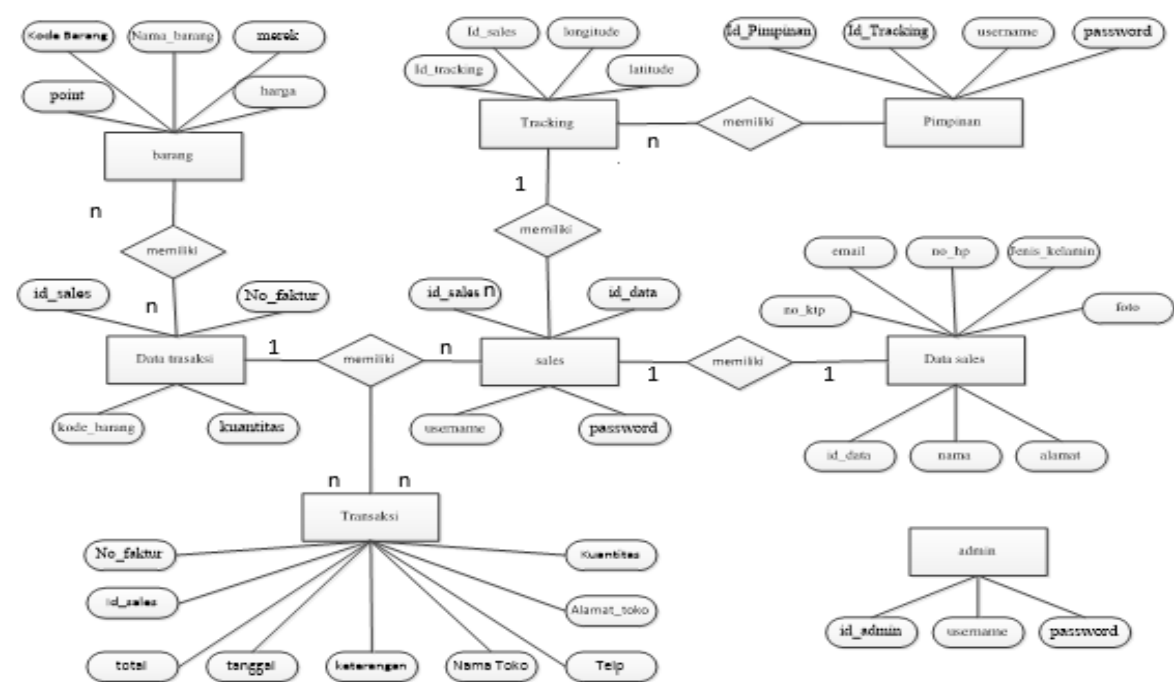

Figure 1. ERD 
3) Implementation
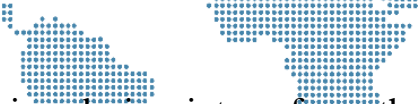

At this stage there is a process of translating the design design into a form that can be understood by the machine, using programmings language codes: The resulting program code is still in the form of small tiondules which will be combined in the next stage.

4) Integration \& Testing

At this stage, the modules that have been made are combined and this test is carried out to find out whether the software made is in accordance with the design and the functions of the software have errors or not.

5) Operation \& Maintenance

This is the last stage in the waterfall model. The finished software is run and maintenance is carried out. Maintenance includes fixing errors not found in the previous step. Improvement of system unit implementation and system service improvement as new requirement.

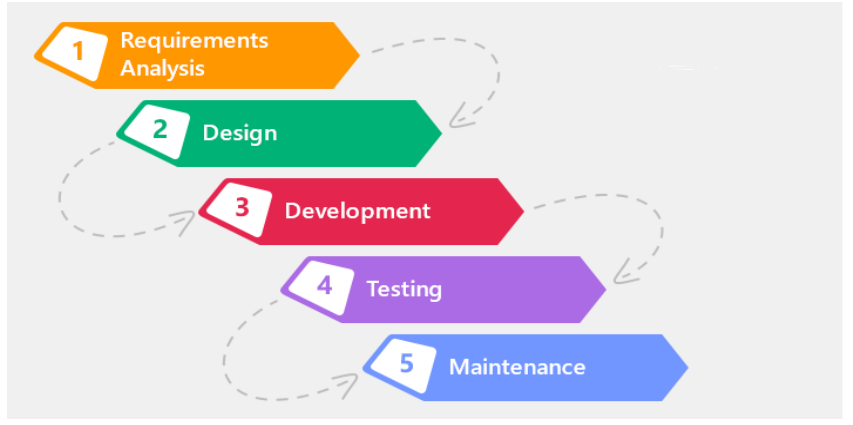

Figure 2. Research Method

\section{Results and Discussion}

1) In this study, several interfaces are needed as a medium of communication with the system, namely:

a. Salesman Login Page

This page is to distinguish the access rights of salesmen and employees or other users. As seen in the image below:

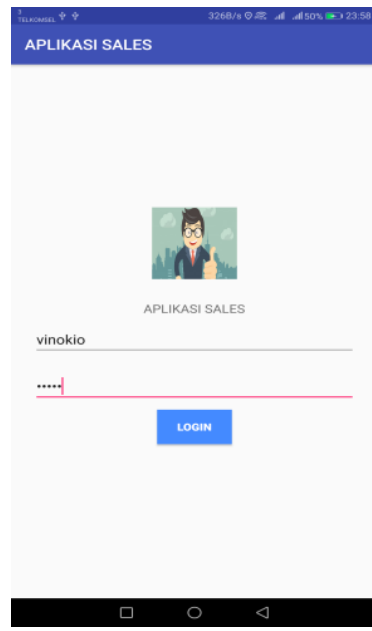

Figure 3. Login

b. Transaction Page

Below is the transaction interface. After all transaction data has been inputted and sales press the save button, all entries sent by the Post method will be stored in their respective variables. 


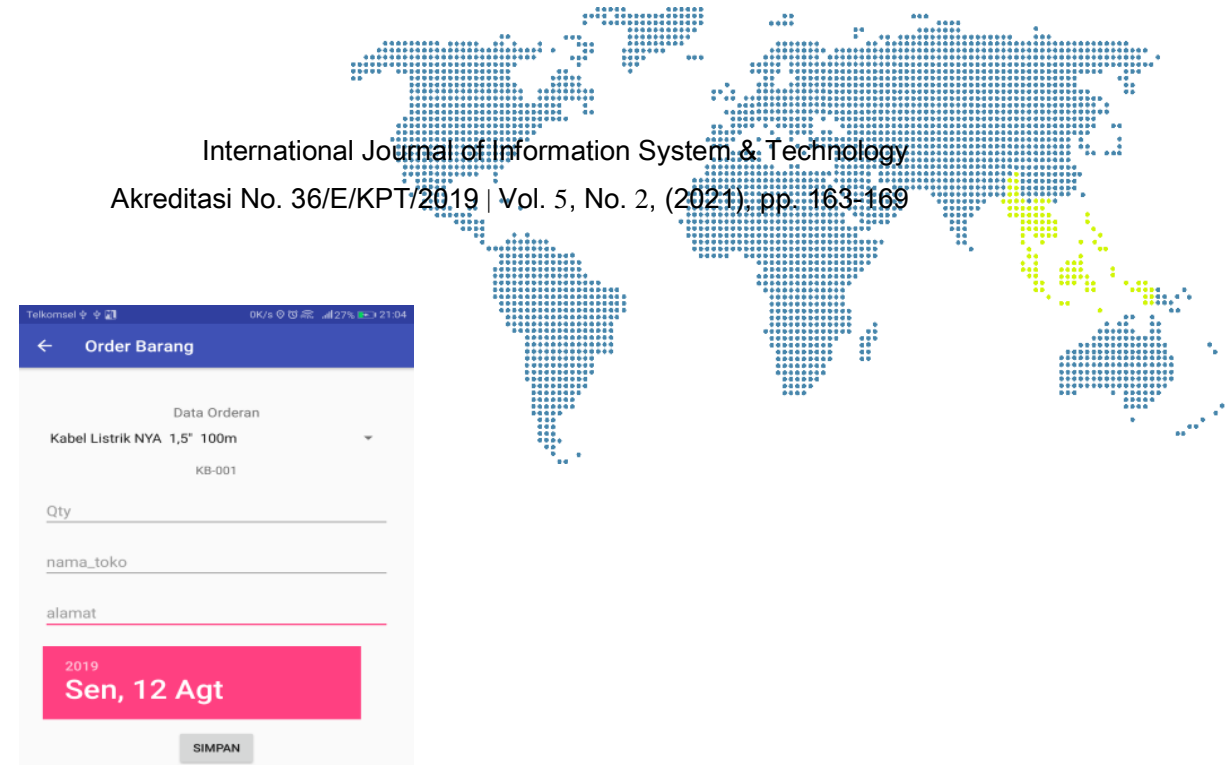

Figure 4. Transaction

c. Transaction Report Page

Transaction page is a manager page to display transaction history that has been done by previous sales.

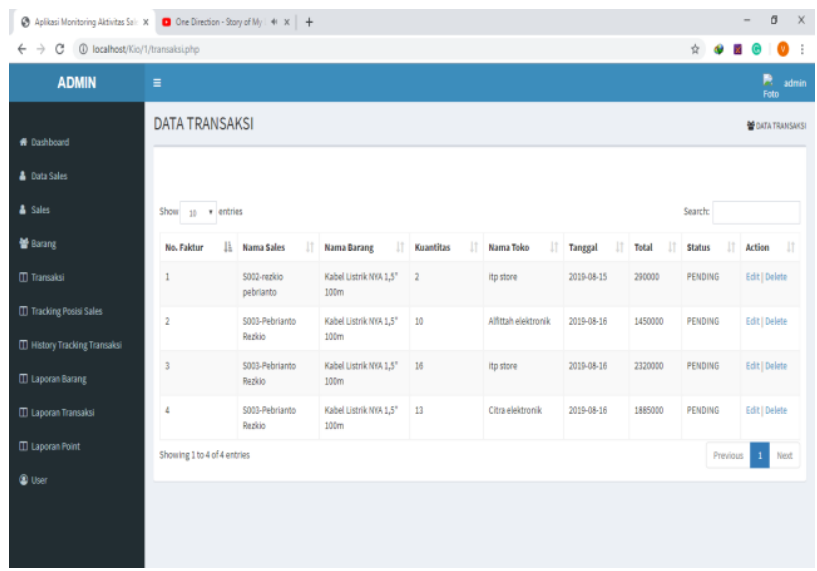

Figure 5. Report

d. Tracking page

The Sales Position Tracking page is a manager page to display the overall position of sales who have logged in to the application.

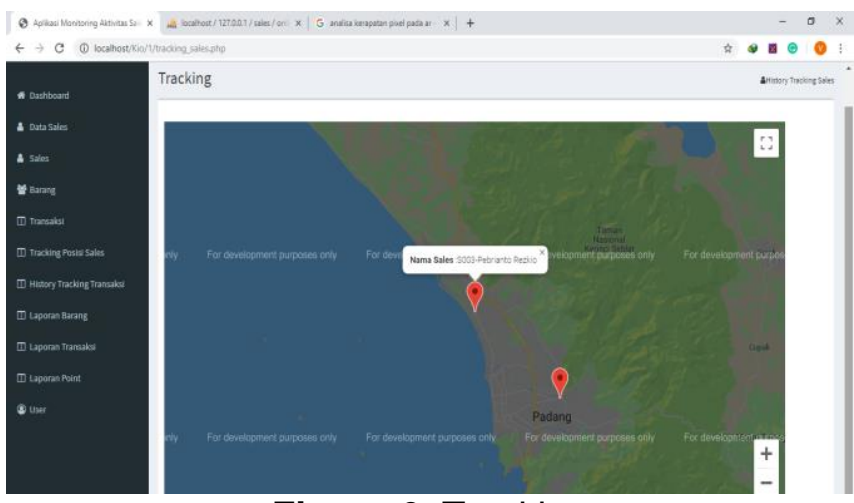

Figure 6. Tracking 


\section{Cisinta}

2) Geolocation and Jquery Latest testing

In this test, it is carried out on a separate prototype from the applecation, namejey script snippets starting from activating geolocation, looping and inserting there is a difference in the last step, which is to insert data. This step aims to see the delay from the input coordinate data. This experiment was carried out 40 - times with data input at 3 different location points with the aim of seeing where the best location for using geolocation was and the number of data errors that occurred. The test locations were carried out indoors, under trees and under tunnels. This test is carried out where the room is effective in using geolocation in taking coordinates if it is not in an open space.

From the test found 2 types of data, the first is coordinate data and $\mathrm{NaN}$ data. $\mathrm{NaN}$ data is obtained from the AJAX process which changes the received data type to a float or decimal data type. In the logical condition of the program that was built, there are times when the condition of the textbox that receives the coordinates is empty and the AJAX process is carried out, when the function is to exchange data types, what happens is that empty data (null) becomes NaN (Not A Number). In statistical data processing, to get the average value (mean) can be done by adding up all the data values of a sample group, then divided by the number of samples as follows.

$$
\bar{x}=\frac{1}{n}\left(x_{1}+x_{2}+\cdots+x_{n}\right)
$$

Table 1. Testing Result

\begin{tabular}{|c|c|c|c|c|c|}
\hline Loc & Fail & Fail (\%) & Successful & Successful (\%) & Delay \\
\hline 1 & 0,3 & 30 & 0,7 & 70 & 0,55 \\
\hline 2 & 0,125 & 12,5 & 0,875 & 87,5 & 0,45 \\
\hline 3 & 0,25 & 25 & 0,75 & 75 & 0,7 \\
\hline
\end{tabular}

It can be concluded that the second test location gets the highest rank compared to other test locations. It can be seen that the highest success rate reaches 0.875 , the lowest failure rate is 0.125 and the smallest delay (distance between data entry) is 0.45 . As seen in Figure 7.

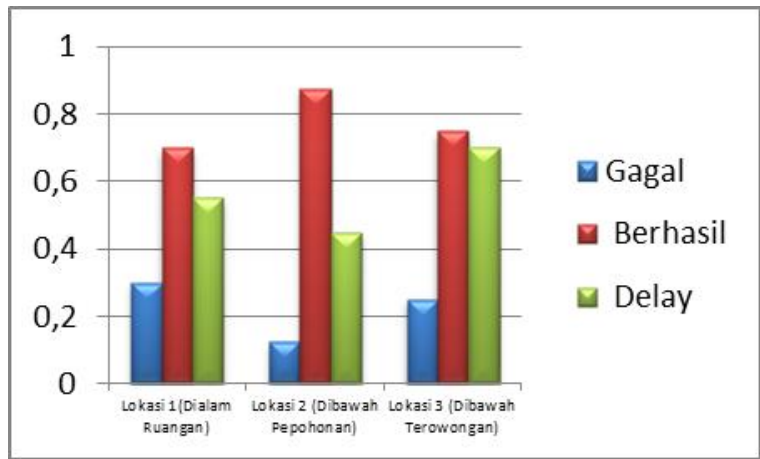

Figure 7. Grafik Perbandingan

\section{Conclusion}

From the tracking system testing carried out on the application that was built, it was found that the tracking system test using Geolocation and jQuery Latest in an open room under conditions under trees got the highest rank compared to other test locations, with a percentage of successful data as much as $77.5 \%$, data failing $12.5 \%$ and the average delay between incoming data is 0.45 seconds per 40 incoming data. On the tracking system side, the use of jQuery Latest causes data errors or data of type NaN (Not A Number) because the condition where the input coordinates from geolocation is refreshed 

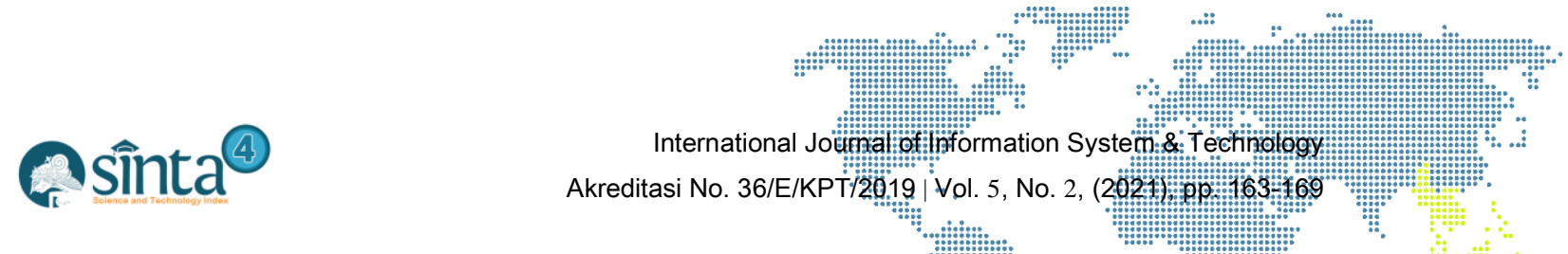

by jQuery Latest, the coordinates are still not filled in and the been carried out or converted into numbers and input to the databoase: This NaN datatalso has an impact on the tracking system interface because there wilu will disappear for a while until it finds the coordinates in the database that is accessed.

\section{References}

[1] Abid, K., dan Ravi, S., 2012, GPS-GSM based Tracking System, International Journal of Engineering trends and Technology-Volume3Issue 2.

[2] Agustina, G. (2011). Sistem Informasi Monitoring Hasil Penjualan Salesman Pada PT. Swarga Gangsing Bandung (Doctoral dissertation, Universitas Komputer Indonesia).

[3] El-Rabbany, Ahmed, 2002, Introduction to GPS, Artech House, Norwood.

[4] Harahap, N. S., 2011, Membangun Aplikasi Mobile Berbasis Android, Informatika, Bandung.

[5] Kusuma, W., \& Septiani, T. (2013). Aplikasi Friend Tracker Berbasis Android Smartphone Menggunakan GPS Tracking. SEMNASTEKNOMEDIA ONLINE, 1(1), $20-13$.

[6] Kramer, M. (2018). Best practices in systems development lifecycle: An analyses based on the waterfall model. Review of Business \& Finance Studies, 9(1), 77-84.

[7] Maarif, S. (2020). Rancang Bangun Aplikasi Kunjungan Sales Berbasis Web-Mobile Pada PT. Xyz Dengan Here Maps Api (Aplikasi visit Mobile) (Doctoral dissertation, Universitas Mercu Buana Jakarta).

[8] Nataliana, D. (2013). Perancangan Dan Realisasi Sistem Transmisi Data GPS Menggunakan Teknologi SMS (Short Messaging Service) Sebagai Aplikasi Sistem Personal Tracking. ELKOMIKA: Jurnal Teknik Energi Elektrik, Teknik Telekomunikasi, \& Teknik Elektronika, 1(1), 48.

[9] Rusnandar, Tedy, S., Wahyu, P., 2013, Sistem Pelacak Kendaraan Berbasis OPENGTS. Jurnal Spektrum Industri, 2013, Vol.11, No.2, 117-242, ISSN: $1963-$ 6590.

[10] Swara, G. Y., \& Pebrianto, R. (2019, October). Implementasi Fitur Tracking Pada Aplikasi Monitoring Aktivitas Sales Berbasis Android. In Seminar Nasional: Peranan Ipteks Menuju Industri Masa Depan (PIMIMD) 2019. 


\section{Csinta}
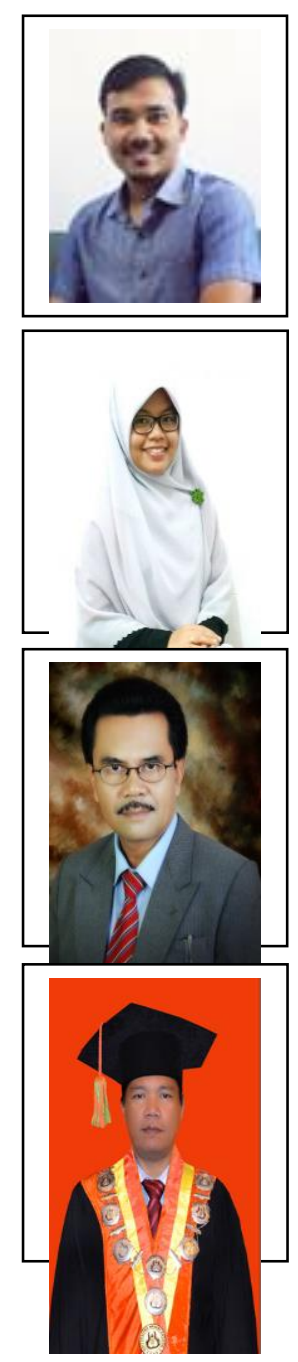

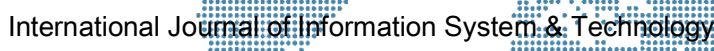

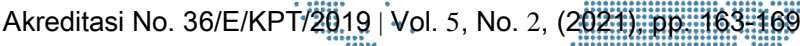

\section{Authors}

Ganda Yoga Swara, M.Kom

Dosen teknik informatika, Institut Teknologgi Padang

\section{Putri Mandarani, M.T}

Dosen teknik informatika, Institut Teknologi Padang

Prof. DR. M. Giatman, MSIE

Dosen Fakultas Teknik, UNP

Drs. Syahril, ST, MSCE, Ph.D

Dosen Fakultas Teknik, UNP 